\title{
CROSS-LINKING OF FIBRIN BY ACTIVATED FACTOR XIII STIMULATES ATTACHMENT, MORPHOLOGICAL CHANGES AND PROLIFERATION OF FIBROBLASTS
}

\author{
SHUNJI KASAI ${ }^{1}$, TAKEHIKO KUNIMOTO ${ }^{2}$ and KAZUO NITTA ${ }^{2}$ \\ ${ }^{1}$ Department of System Engineering for Materials, Faculty of Technology, Tokyo University of Agriculture and \\ Technology, Koganei, Tokyo 184, and ${ }^{2}$ Chemotherapy Division, National Cancer Center Research Institute, \\ Tsukiji, Chuoku, Tokyo 104, Japan
}

\begin{abstract}
The response of fibroblasts to the conversion of fibrinogen into fibrin was investigated to clarify the relationship between the conversion and wound healing. The formation of fibrin by thrombin little affected fibroblast attachment and morphology. In contrast cells rapidly attached and subsequently spread on fibrin cross-linked by activated Factor XIII. The introduction of cross-linking also stimulated cell proliferation. However neither enzyme had much effect on cellular behavior. These results indicate that the introduction of cross-linking by activated Factor XIII directly promotes the cellular responses, and suggest that the formation of fibrin stabilized by cross-linking plays a significant role not only in stoppage of blood flow but also in subsequent migration and proliferation of fibroblasts.
\end{abstract}

The conversion of fibrinogen into fibrin is the terminal step in blood clotting. In this process, thrombin cleaves fibrinogen to release sequentially fibrinopeptide $\mathrm{A}$ and fibrinopeptide $\mathrm{B}$. This trimming results in the spontaneous polymerization of the molecules. Although the first stage of fibrin polymerization by thrombin does not involve covalent bonds, the polymer is subsequently stabilized by the introduction of intermolecular $\gamma$-glutamyl- $\epsilon$-lysine peptide bonds. The formation of these covalent bonds between side chains is catalyzed by an enzyme called activated Factor XIII or fibrin-stabilizing factor (FSF). Factor XIII deficiency, first described by Duckert et al. $(1,5)$, is characterized by recurrent bleeding, hematoma formation after trauma, prolonged wound healing, and extensive scarring. The stimulation of fibroblast proliferation and collagen formation

${ }^{1}$ Present address: Biotechnology Center, The Green Cross Corporation Research Division, Hirakata, Osaka 573, Japan are required in wound healing (8). Thus the delay of wound healing in Factor XIII-deficiency patients may be due to the lack of stimulation of fibroblast proliferation.

To clarify the relationship between the conversion of fibrinogen into fibrin and wound healing, we investigated the responses of fibroblasts to the conversion. In this study serumfree defined medium was used to eliminate effects of hormones, growth factors and coldinsoluble globulin present in serum.

\section{MATERIALS AND METHODS}

\section{Purification of Fibrinogen}

Fibrinogen free of blood coagulation Factor XIII and plasminogen was prepared by treating bovine fibrinogen (Daiichi Pure Chemicals Co.; $97 \%$ clottable) with $3.3 \mathrm{M}$ urea (17) and lysineSepharose affinity chromatography (19). The solution containing fibrinogen was dialyzed against $0.14 \mathrm{M}$ sodium chloride buffered at $\mathrm{pH} 7.4$ with $0.01 \mathrm{M}$ Tris- $\mathrm{HCl}(\mathrm{NaCl} /$ Tris- $\mathrm{HCl})$ and stored in portions at $-20^{\circ} \mathrm{C}$. 


\section{Conversion of Fibrinogen into Fibrin}

Non-cross-linked and cross-linked fibrin were prepared in the following manner $(13,14,17)$. An aliquot of fibrinogen solution was placed in a $35-\mathrm{mm}$ culture dish. Fibrin formation was initiated by adding a solution containing thrombin (Sigma Chem. Co.) and $\mathrm{CaCl}_{2}$. The final concentrations were $2 \mathrm{mg} / \mathrm{ml}$ fibrinogen; $20 \mathrm{mM}$ $\mathrm{CaCl}_{2} ; 2$ units $/ \mathrm{ml}$ thrombin. When exogenous Factor XIII (The Green Cross Co.; specific activity 10 units/mg protein) was to be included in the clotting mixture, it was added to the fibrinogen solution before the addition of the thrombin- $\mathrm{CaCl}_{2}$ mixture. In this case the final concentration of Factor XIII was 0.1 unit $/ \mathrm{ml}$. The reaction mixtures were incubated at $37^{\circ} \mathrm{C}$ for $6 \mathrm{~h}$. The formed gel was rinsed twice with Hanks' balanced salt solution (HBSS) before addition of the cells.

In some experiments, fibrinogen dissolved in $\mathrm{NaCl} /$ Tris- $\mathrm{HCl}(2 \mathrm{mg} / \mathrm{ml})$ was placed in a culture dish. It was incubated at $22^{\circ} \mathrm{C}$ for $20 \mathrm{~min}$, washed twice with HBSS, and used as a fibrinogen-treated substratum.

\section{Sodium Dodecyl Sulfate (SDS)-Polyacryl- amide Gel Electrophoresis}

Prior to electrophoresis, samples were reduced for $10 \mathrm{~min}$ at $100^{\circ} \mathrm{C}$ in $4 \mathrm{M}$ urea, $1 \%$ sodium dodecyl sulfate, and 1\% 2-mercaptoethanol as described by Mosher (13). Polyacrylamide gel electrophoresis in $0.1 \%$ sodium dodecyl sulfate was performed using the method of Laemmli (7). The gel was stained with Coomassie brilliant blue and destained by diffusion (18).

\section{Cells}

$\mathrm{L}$ cells were grown in stationary culture in Eagle's minimal essential medium (Eagle's MEM) supplemented with $10 \%$ fetal bovine serum (FBS) and $60 \mu \mathrm{g}$ of kanamycin per $\mathrm{ml}$.

\section{The Kinetics of Cell Attachment}

$\mathrm{L}$ cells were dispersed from the monolayer with $0.25 \%$ trypsin (Flow Laboratories Co.) and $0.02 \%$ ethylenediaminetetraacetate (EDTA) in phosphate-buffered saline (PBS). The detached cells were harvested by centrifugation, washed once with HBSS containing bovine serum albumin (BSA) at $10 \mathrm{mg} / \mathrm{ml}$, and resuspended in Eagle's MEM. L cells $\left(5 \times 10^{5}\right.$ cells $)$ in $1.5 \mathrm{ml}$ of Eagle's MEM were placed in fibrinogen- or fibrin-treated culture dishes. The dishes were incubated at $37^{\circ} \mathrm{C}$ in a $5 \% \mathrm{CO}_{2}$ atmosphere. The number of adherent cells was determined at various times by counting the number of nonadherent cells recovered in the medium and subtracting this number from the number of cells initially placed in the dish (16).

\section{Cell Growth in Serum-Free Medium}

For growth assay, L cells $\left(4 \times 10^{4}\right.$ cells $)$ suspended in Eagle's MEM supplemented with $1 \%$ BSA were placed in culture dishes that had been treated with either fibrinogen or fibrin, and incubated at $37^{\circ} \mathrm{C}$ in a $5 \% \mathrm{CO}_{2}$ atmosphere. At the end of the incubations the medium was decanted and the cells were released with $0.25 \%$ trypsin and $0.02 \%$ EDTA in PBS. The number of released cells was counted in a hemocytometer.

\section{RESULTS}

\section{Cross-Linking of Fibrin by Activated Factor XIII}

The fibrinogen molecule is composed of three pairs of disulfide-linked nonidentical polypeptide chains $\left(\alpha_{2} \beta_{2} \gamma_{2}\right)(11,12)$. Thrombin catalyzes the conversion of fibrinogen into fibrin, but cross-linking is not introduced in this polymerizing reaction. On the other hand, activated Factor XIII catalyzes the formation of intermolecular $\epsilon$-( $\gamma$-glutamyl)lysine cross-linking between side chains, converting noncovalently linked fibrin into a covalent linked form $(9,10,15)$.

Fig. 1 shows the SDS-polyacrylamide gel electrophoretic patterns of reduced purified bovine fibrinogen, non-cross-linked fibrin and cross-linked fibrin. In the present experiment, cross-linking formation by activated Factor XIII was confirmed.

\section{Time Course of Fibroblast Attachment}

$\mathrm{L}$ cells attached more rapidly to fibrin-treated substrata than to fibrinogen-treated substrata (Fig. 2). Furthermore, clear differences were observed in the rate of cell attachment between non-cross-linked fibrin and cross-linked fibrin used as substrata. The results indicate that not only the formation of fibrin matrix but also the introduction of cross-linking by activated Factor XIII affect fibroblast attachment. 


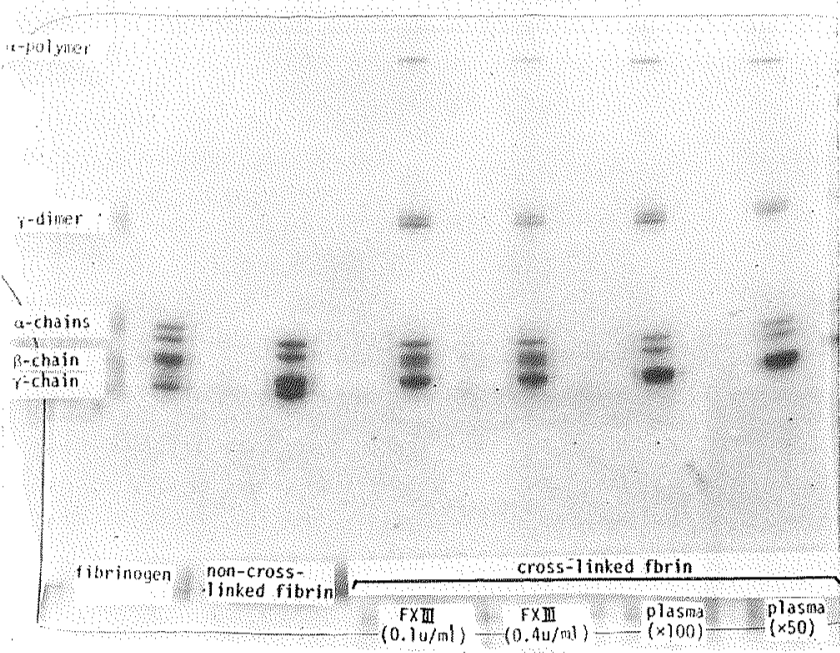

Fig. 1 Polyacrylamide gel electrophoresis in sodium dodecyl sulfate of fibrinogen, non-cross-linked fibrin, and cross-linked fibrin. Samples were reduced for $10 \mathrm{~min}$ at $100^{\circ} \mathrm{C}$ in $4 \mathrm{M}$ urea, $1 \%$ sodium dodecyl sulfate, and $1 \% 2$-mercaptoethanol prior to electrophoresis, and $7.5 \mu \mathrm{g}$ was subjected to electrophoresis on $7.5 \%$ gel.

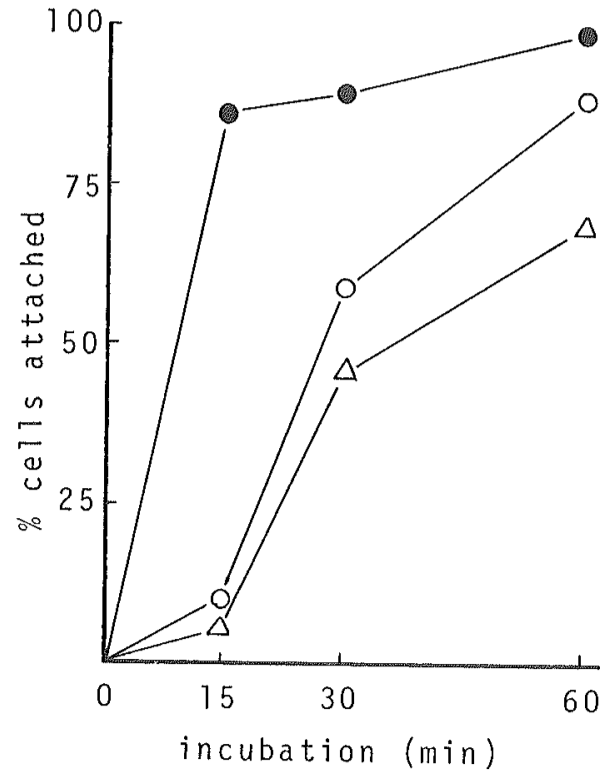

Fig. 2 Time course of $\mathrm{L}$ cell attachment to the substrata treated with fibrinogen $(\Delta)$, non-crosslinked fibrin (O), and cross-linked fibrin (

\section{Morphology of Attached Cells}

Fig. 3 shows the morphology of attached cells on the substrata treated with fibrinogen, noncross-linked fibrin, or cross-linked fibrin. On fibrinogen-treated, or non-cross-linked fibrintreated substrata, only partial or no cell spreading was observed. In contrast, when cells were seeded on cross-linked fibrin-treated substrata, they spread rapidly. Within $30 \mathrm{~min}$, all cells spread fully. It is therefore likely that the introduction of cross-linking by activated Factor XIII markedly affects both the rate of cell attachment and morphology.

\section{Relationship between Conversion of Fibrinogen into Fibrin and Fibroblast Growth}

Cell growth on the substrata treated with fibrinogen, non-cross-linked fibrin, or crosslinked fibrin were compared. As shown in Fig. 4 , the growth rate of $\mathrm{L}$ cells depends on the provided substrata. $L$ cells failed to proliferate on culture dishes in the BSA-supplemented, serum-free medium.

On the other hand, different growth response of $\mathrm{L}$ cells to the conversion of fibrinogen into fibrin was observed. In the experiment presented in Fig. 4, L cells grew best on the substrata treated with cross-linked fibrin and became confluent (Fig. 5).

\section{DISCUSSION}

The present study demonstrates that the conversion of fibrinogen into fibrin directly affects not 


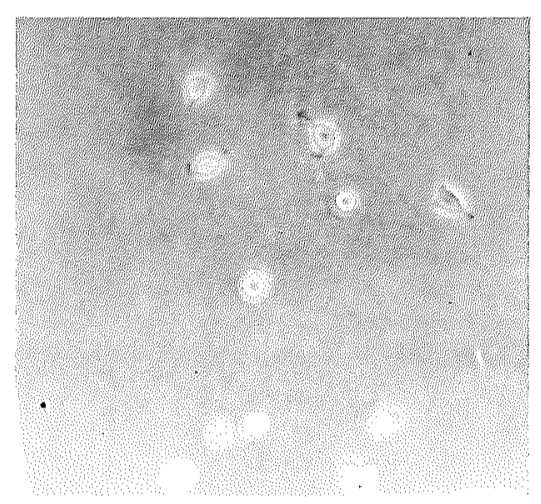

fibrinogen

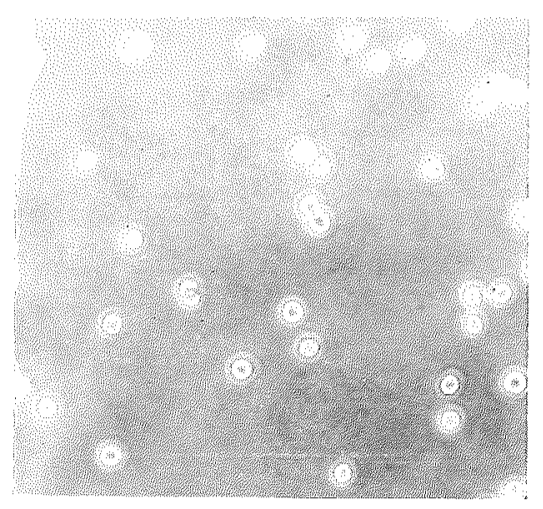

non-cross-linked fibrin

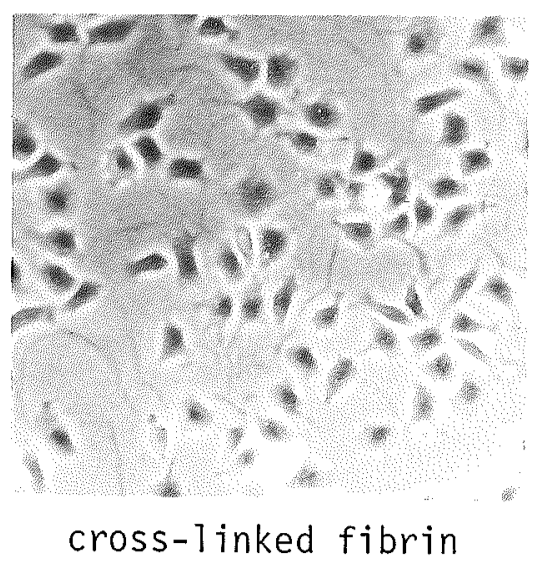

Fig. 3 L cell spreading on the substrata treated with fibrinogen, non-cross-linked fibrin, and cross-linked fibrin. Cells were incubated at $37^{\circ} \mathrm{C}$ for $30 \mathrm{~min}$ on the substrata treated with fibrinogen, non-crosslinked fibrin, or cross-linked fibrin. Then they were photographed with an Olympus IMT inverted microscope and an Olympus PM-10 AD $35 \mathrm{~mm}$ camera system. $\times 100$ only the rate of fibroblast attachment and fibroblast morphology but also growth on the substrata, and that these effects are due to the introduction of cross-linking between fibrin fibers by activated Factor XIII.

Fibrinogen molecules are converted to fibrin by thrombin, followed by the introduction of intermolecular $\gamma$-glutamyl- $\epsilon$-lysine bonds by activated Factor XIII. The formation of fibrin by thrombin little affected cell attachment (Fig. 2) or morphology (Fig. 3). In contrast, cells rapidly attached and subsequently spread on the substrata treated with cross-linked fibrin. Furthermore, introduction of cross-linking by activated Factor XIII stimulated cell proliferation (Fig. 4).

Several investigators reported that thrombin and activated Factor XIII directly affect the growth of some types of cells $(2,6)$. But neither enzyme had much effect on the attachment, morphology, or growth of $\mathrm{L}$ cells in the concen-

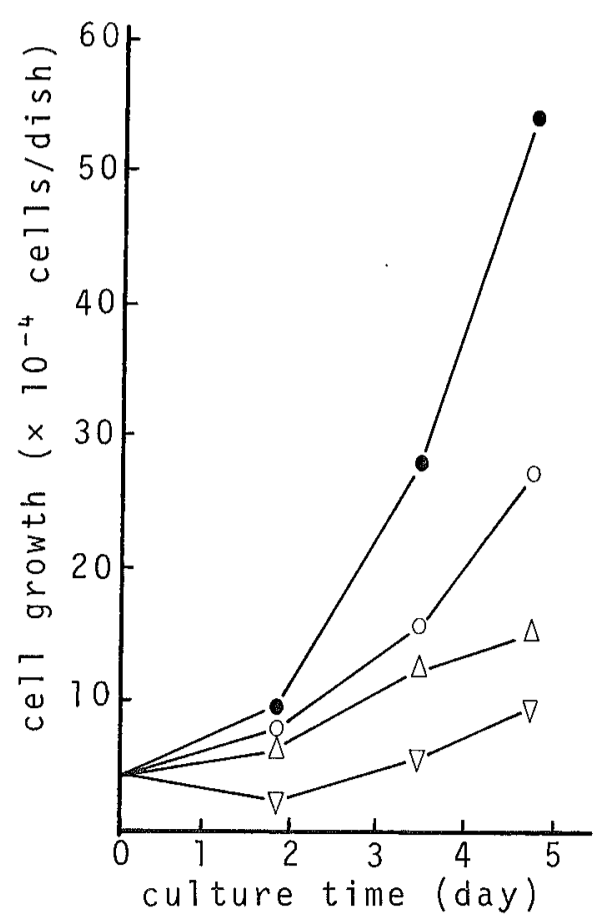

Fig. 4 L cell growth on the substrata treated with fibrinogen, non-cross-linked fibrin, and cross-linked fibrin. L cells $\left(4 \times 10^{4}\right.$ cells) suspended in Eagle's MEM supplemented with $1 \%$ BSA were placed in culture dishes that had been treated with fibrinogen $(\Delta)$, non-cross-linked fibrin $(O)$, or cross-linked fibrin $(\bullet)$, or were untreated $(\nabla)$. All were incubated at $37^{\circ} \mathrm{C}$ in a $5 \% \mathrm{CO}_{2}$ atmosphere. 


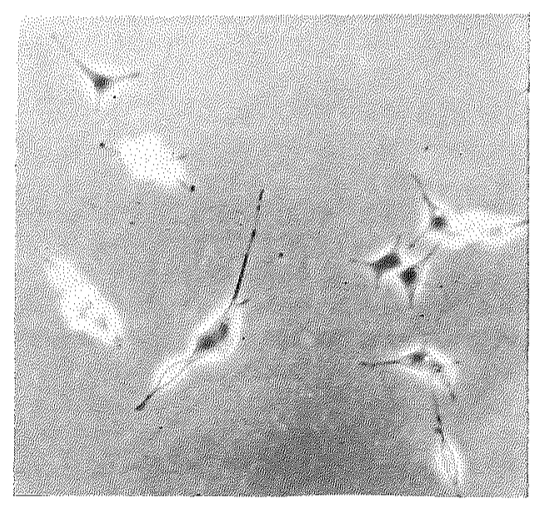

fibrinogen

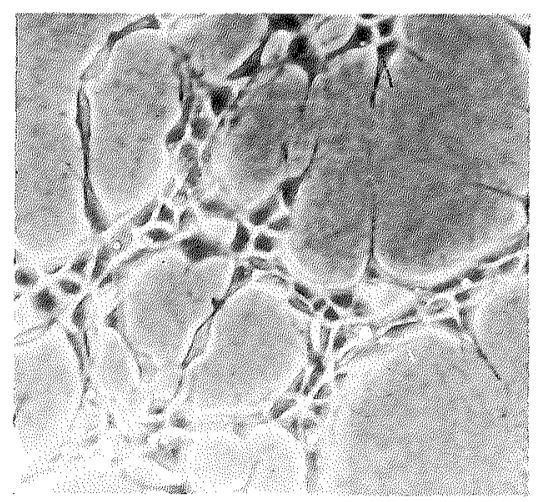

non-cross- 1 inked fibrin

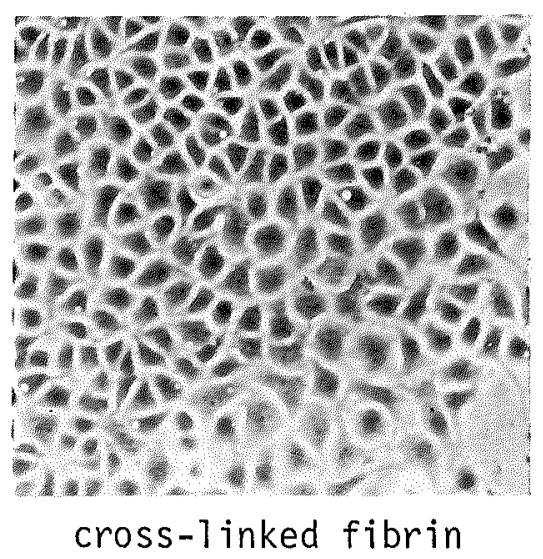

Fig. 5 Morphological appearance of $\mathbf{L}$ cells maintained on the substrata treated with fibrinogen, non-cross-linked fibrin, or cross-linked fibrin. Cultures were placed and maintained as described in Fig. 4. Pictures were taken at 115 h. $\times 100$ trations used in this study (data not shown). Thus the possibility can be ruled out that thrombin or activated Factor XIII directly stimulate the cells. We conclude that the introduction of cross-linking between fibrin fibers directly promotes the cellular responses. Our results suggest that the formation of fibrin stabilized by cross-linking plays a significant role not only in stoppage of blood flow but also in subsequent migration and proliferation of fibroblasts.

Cross-linked fibrin is mechanically stronger than non-cross-linked fibrin and is also more resistant to enzymatic dissolution. Doolittle $(3,4)$ suggested that no morphological difference is found between the two in electron microscopy, and that cross-linking does not seem to introduce gross structural rearrangement.

Detailed interaction mechanism between the introduction of cross-linking and alteration of cellular behavior remains unknown. Further studies are presently being carried out to clarify not only how cross-linked fibrin interacts with the cell surface and cytoskeleton to affect their attachment, morphology, and proliferation, but also what difference in biological roles exists between the formation of $\gamma$-dimer and $\alpha$-polymer subunits of cross-linked fibrin.

Received for publication 20 December 1982; and in revised form 31 Jamuary 1983

\section{REFERENCES}

1. Beck E., Duckert F. and Erust M. (1961) The influence of fibrin-stabilizing factor on the growth of fibroblasts in vitro and wound healing. Thromb. Diath. Haemorth. 6, 485-491

2. Carney D. H., Glenn K. C, and Cunningham D. D. (1978) Conditions which affect initiation of animal cell division by trypsin and thrombin. J. Cell. Physiol. 95, 13-22

3. Doolittle R. F. (1975) Fibrinogen and fibrin. In Plasma Proteins Vol. 2 (ed. Putnam F. W.) Academic Press, New York, pp. 109-159

4. Doolittle R. F. (1981) Fibrinogen and fibrin. Scientific American 245, 92-101

5. Duckert F., Jung E. and Schmerling D. H. (1960) A hitherto undescribed congenital haemorrhagic diathesis probably due to fibrin stabilizing factor deficiency. Thromb. Daith. Haemomh. 5, 179-186

6. Hall W. M. and Ganguly P. (1980) Differential effect of thrombin on the growth of human fibroblasts. J. Cell Biol. 85, 70-82

7. LAEMMLi U. K. (1970) Cleavage of structural proteins during the assembly of the head of bacteriophage T4. Nature 227, 680-685

8. Leibovich S. J. and Ross R. (1975) The role of the macrophage in wound repair. A study with 
hydrocortisone and antimacrophage serum. Amer. J. Pathol. 78, 71-100

9. Lorand L., Downey J., Gotoh T., Jacobsen A. and Tokura S. (1968) The transpeptidase system which cross-links fibrin by $\gamma$-glutamyl- $\epsilon$-lysine bonds. Biochem. Biophys. Res. Commum. 31, 222-230

10. Matačić S. and Loewy A. G. (1968) The identification of isopeptide crosslinks in insoluble fibrin. Biochem. Biophys. Res. Commum. 30, 356362

11. McKee P. A., Mattock P. and Hill R. L. (1970) Subunit structure of human fibrinogen, soluble fibrin, and cross-linked insoluble fibrin. Proc. Natl. Acad. Sci. USA 66, 738-744

12. McKee P. A., Rogers L. A., Marler E. and HILl R. L. (1966) The subunit polypeptides of human fibrinogen. Arch. Biochem. Biophys. 116, 271-279

13. Mosher D.F. (1975) Cross-linking of coldinsoluble globulin by fibrin-stabilizing factor. J. Biol. Chem. 250, 6614-6621

14. Mosher D. F., Schad P. E. and VanN J. M.
(1980) Cross-linking of collagen and fibronectin by Factor XIIIa. Localization of participating glutaminyl residues to a tryptic fragment of fibronectin. J. Biol. Chem. 255, 1181-1188

15. Pisano J. J., Finlayson J. S. and Peyton M. P. (1968) Cross-link in fibrin polymerized by Factor XIII : $\epsilon$-( $\gamma$-glutamyl)lysine. Science 160, 892-893

16. Schor S. L. and CourT J. (1979) Different mechanisms in the attachment of cells to native and denatured collagen. J. Cell Sci. 38, 267-281

17. Schwartz M. L., Pizzo S. V., Hill R. L. and MCKeE P. A. (1971) The effect of fibrin-stabilizing factor on the subunit structure of human fibrin. J. Clin. Invest. 50, 1506-1513

18. WEBER K. and OSBORN M. (1969) The reliability of molecular weight determinations by dodecyl sulfate-polyacrylamide gel electrophoresis. $J$. Biol. Chem. 244, 4406-4412

19. Wu M.-C., Schultz D. R. and Arimura G. K. (1975) Characteristics of fibrinolysin secreted by cultured rat breast carcinoma cells. Exp. Cell Res. 96, 37-46 